\title{
All Citizens are Created Equal, but Some are More Equal Than Others
}

\author{
Laura van Waas ${ }^{1,2} \cdot$ Sangita Jaghai ${ }^{1,2}$
}

Published online: 30 November 2018

(c) The Author(s) 2018

\begin{abstract}
Nationality is the legal bond between a person and a state that connotes full and equal membership of the political community. Yet, in the practice of states, not everyone who is admitted as a national enjoys the full package of rights attached, nor the same security of status. The phenomenon of inequality among citizens is particularly apparent when examining the question of how protected the legal bond itself is: citizenship by birth is more secure than citizenship acquired otherwisesuch as by naturalisation - and mono citizens are less prone to withdrawal of nationality than persons with dual or multiple nationality. As nationality revocation gains new attention from states as a tool to counter terrorism, prompting much political, public and academic debate, the reality that this measure often applies only to particular sub-groups of citizens demands closer scrutiny. This article explores how law and practice on citizenship deprivation is to be evaluated against contemporary standards of international law. While states justify unequal application of citizenship deprivation measures by invoking the duty to avoid statelessness, this article shows that the application of other international standards such as non-discrimination and the prohibition of arbitrary deprivation of nationality calls into question the legitimacy of citizenship stripping as a security instrument. Finally, the article reflects on the broader implications of the current trend towards greater inequality of citizenship status as a reaction to the perceived threat that terrorism poses to the integrity of the state, discussing how the creation of different classes of citizen is in fact likely to have a deeper and more lasting impact on the foundations of liberal democracies.
\end{abstract}

Keywords Equality $\cdot$ Citizenship $\cdot$ Nationality $\cdot$ Deprivation $\cdot$ Discrimination Statelessness

\footnotetext{
This article draws on research conducted by the authors in preparation for an Expert Roundtable on Citizenship Stripping as a National Security Measure, convened in The Hague in June 2018 by the Institute on Statelessness and Inclusion, Open Society Justice Initiative, the Asser Institute and Ashurst. It is also informed by the overall direction of discussions at that Roundtable, the report of which is forthcoming.
}

Extended author information available on the last page of the article 


\section{Introduction}

Under the headline 'World's Top Nationalities Revealed', Forbes magazine reported that a global index declared France to have the 'best' nationality on offer in the world in 2018, in terms of 'quality of life and opportunity'. ${ }^{1}$ The index is fed by quantitative data that aims to expose what it calls the internal and external quality of a particular nationality - across categories such as economic prosperity, peace and security (internal), and the scope of visa-free travel (external). ${ }^{2}$ This ranking of nationalities, and the citizenship-by-investment schemes is being used to promote and remind us of the pervasiveness of global inequality. Although the contemporary international legal order is based on the principle of the sovereign equality of all states, rendering the world's nationalities formally equal, in practice there is what Shachar calls an 'inequality of actual life chances attached to citizenship in specific political communities'. ${ }^{3}$ Even in an era of human rights, which recognise 'the equal and inalienable rights of all members of the human family', this remains the reality. It matters, not just whether you have a nationality, ${ }^{5}$ but which nationality that is.

While Shachar problematises these 'global-distributive implications' of citizenship and its attendant rules in his compelling monograph The Birthright Lottery, this article explores another plane of inequality within modern citizenship regimes that has received little attention to date: the unequal nationality status of different members of the same political community. The concept of nationality-or citizenship ${ }^{6}$-refers to the legal bond between a person and a state, ${ }^{7}$ that 'connotes full membership'. ${ }^{8}$ In liberal democracies, citizenship brings with it the often constitutionally guaranteed promise of equality of rights (and duties) within that community. ${ }^{9}$ Nowhere within this understanding of nationality is there anything to suggest that the nature of the legal bond varies among citizens of the same community, i.e. that some citizens are more equal than others. Yet, in the practice of states, not

\footnotetext{
1 Southan (2018). The article is reporting on the 2017 edition of the Quality of Nationality Index, maintained by Henley \& Partners - a private consulting firm that advises high wealth individuals on how to improve their own opportunity through 'citizenship planning'.

2 A description of the methodology behind the Index is available at: https://www.nationalityindex.com/ methodology (accessed 20 July 2018).

3 Shachar (2009), p. 9. Shachar goes on to expose how in such a world, citizenship laws assigning political membership by birthright play a crucial role in the distribution of basic social conditions and life opportunities on a global scale', acting as a means of 'sustaining the privilege of inherited entitlement'. Ibid., p. 3.

4 Preamble, Universal Declaration of Human Rights, 1948.

5 The disadvantage generated by statelessness is widely documented, in both scholarly research and studies by the UN and civil society, as well as artists. See, for instance, Belton (2017), Institute on Statelessness and Inclusion (2017), Constantine (2015), UN Human Rights Council (2015), UNHCR (2014), Blitz and Lynch (2009).

6 The terms nationality and citizenship are used interchangeably here, as they are in much of the legal literature on this topic. See further Edwards (2014), pp. 13-14.

7 Nottenbohm case (1955), ICJ Reports 1955, p. 4.

8 Weis (1979), p. 4.

9 See for constitutional provisions on equality the Constitute Project, available at: https://www.constitute project.org/ (accessed 20 July 2018).
} 
everyone who is admitted as a national enjoys the full package of rights attached, nor the same security of status. Examples of this manifestation include restrictions on the exercise of political rights by particular categories of nationals, such as dual citizens ${ }^{10}$ or the (newly) naturalised, ${ }^{11}$ as well as unequal ability to transmit citizenship and contribute to further shaping the community. ${ }^{12}$

The phenomenon of inequality among citizens is also apparent when examining how protected the legal bond itself is. As this article will expose, when it comes to the power of states to divest a person of his or her nationality, it matters both how that nationality was acquired and whether it is the only one the person in question holds. Citizenship by birth is more secure than citizenship acquired otherwise- such as by naturalisation - and mono citizens are less prone to withdrawal of nationality than persons with dual or multiple nationality. As will be shown in Sect. 2, such inequality is a long-standing feature of the rules on loss and deprivation of nationality across a wide array of countries. Yet, it has drawn increased attention in recent years on account of the growing interest among states to use nationality deprivation as a counter-terrorism measure and become a much-scrutinised topic within related political, public and academic debate. Indeed, as Sect. 3 will discuss, the uptake in legislation on and use of citizenship stripping on the pretext of protecting national security has shone new light on not only the unequal scope of the measure, but also the discriminatory effects of its application. This raises the question of how such law and practice is to be evaluated against contemporary standards of international law. Section 4 explores the apparent contradiction between, on the one hand, norms that inform states' duty to avoid statelessness and, on the other, the principles of non-discrimination and of equality before the law, discussing how this might be reconciled. Finally, the article reflects on the broader implications of the current trend towards greater inequality of citizenship status as a reaction to the perceived threat that terrorism poses to the integrity of the state, discussing how the creation of different classes of citizen is in fact likely to have a deeper and more lasting impact on the foundations of liberal democracies.

\footnotetext{
${ }^{10}$ In Australia, for instance, a section of the Constitution that regulates eligibility to sit as a Senator or member of the House of Representatives was interpreted by the High Court as barring dual nationals from running for office. This made international headlines in 2017 when a 'dual-nationality crisis' ensued from the discovery that several sitting parliamentarians held a second citizenship, forcing their resignation. See BBC report How a dual citizenship crisis befell an immigrant nation, available at: https ://www.bbc.com/news/world-australia-40773930 (accessed 20 July 2018).

11 In Kuwait, for instance, there is a waiting period of 30 years following acquisition of citizenship by naturalisation before voting rights can be exercised and citizens by naturalisation are barred from standing for election themselves. Similar rules apply in several of the other Gulf states. See van Waas (2014), p. 17.

12 The most striking example of this is the enduring inequality of female as compared to male citizens. In 25 countries globally, women are not entitled to pass their nationality to their children on equal terms as men; while in more than 50 countries there are unequal rules relating to the conferral of nationality to a foreign spouse. Govil and Edwards (2014) and UNHCR (2018).
} 


\section{Deprivation of Nationality: An Unequal Measure?}

Across the world, states provide in their laws for the possibility of involuntary withdrawal of a citizen's nationality. In some instances, a distinction is drawn between loss and deprivation of nationality. ${ }^{13}$ Loss then refers to a situation in which nationality is withdrawn automatically, by operation of law (i.e. without state interference). For example, in some states nationality can be automatically lost if a person resides abroad for a consecutive period determined by law. ${ }^{14}$ Once the conditions specified in law are fulfilled, the person's nationality lapses automatically. Deprivation of nationality, in contrast, is non-automatic and requires the state to decide in each individual case whether citizenship should be revoked, in accordance with powers stipulated in national legislation. Often, the assigned state authority (e.g. Minister of Justice or a judge) has some discretion in determining whether a person's behaviour should lead to denationalisation. Under the 1961 Convention on the Reduction of Statelessness (1961 Convention), different standards apply to specific forms of loss and of deprivation of nationality, however both modalities of withdrawal of citizenship are also subject to the broader human rights norm prohibiting arbitrary deprivation of nationality-i.e. no distinction between loss and deprivation of citizenship is made in human rights law. ${ }^{15}$ In practice, national legislation also does not always clearly distinguish between loss and deprivation of nationality and both lead to a person who was once a citizen being left without that status. In this article, the terms loss and deprivation of nationality will therefore be used interchangeably.

The problematisation of nationality deprivation as an unequal measure has recently emerged as an area of debate in the context of contemporary counter-terrorism efforts which have heralded an increased use of this policy. ${ }^{16}$ Yet, deprivation clauses have been stipulated in most nationality laws since their inception. Historically, denationalisation was invoked against citizens who were disloyal towards the state, posed an imminent threat to national security or no longer had a bond with the state. For example, the 1892 Dutch Citizenship Act, Article 7(4) states: '[Nederlanderschap wordt verloren:] door zonder Ons verlof zich te begeven in vreemden krijgs- of staatsdienst'. ${ }^{17}$ In short, Dutch nationality will be lost by any Dutch citizen who joins a foreign military or public service. Being a citizen required having undivided allegiance towards your country, including the duty to support and defend it, and denationalisation was seen as a way to deal with disloyal and undesirable citizens.

That nationality deprivation is a measure of unequal application is apparent already in early comparative studies of domestic legislation. In 1953, the

\footnotetext{
131961 Convention on the Reduction of Statelessness; UN Human Rights Council (2013), para. 3.

14 For instance, Art. 15(1)(c) Rijkswet op het Nederlanderschap (Dutch Nationality Act).

15 UN Human Rights Council (2009), para. 23. See further also Sect. 4 of this article.

16 Choudhury (2017), p. 227; Macklin (2015a), p. 1.

17 A translation of the original nationality act reads as follows: Netherlands citizenship will be revoked if a person joins a military or public service without permission of the state. Wet van 12 December 1892 op het Nederlanderschap en het ingezetenschap, Staatsblad [Offical Gazette] 1892 no. 268.
} 
International Law Commission (ILC) published a memorandum that gives an overview of the common nationality deprivation grounds that existed around the world at that time. ${ }^{18}$ While some grounds applied to all citizens, the study also pointed out countries that only apply nationality deprivation grounds to naturalised citizens. ${ }^{19}$ Loss of nationality could, for instance, occur if a naturalised citizen lives abroad for a specified period of time or if a naturalised citizen fraudulently acquired the nationality. Naturalised citizens could also lose their citizenship if they were convicted of a serious crime within a specified number of years after naturalisation. In some states, 'denaturalisation' could take place at any time if a citizen was convicted of treason or for a crime against the security of the state or could be invoked if a naturalised citizen 'indicated oneself to be disloyal, disaffected or of a mentality contrary to the national spirit'. ${ }^{20}$ Denaturalisation was the first form of unequal citizenship stripping, causing a divide between naturalised citizens and native-born citizens.

Another phenomenon of unequal nationality deprivation apparent at that time was the inequality between men and women. In the early to mid-twentieth century it was deemed in the general interest of the international community to ensure that everyone had a nationality, but one nationality only. ${ }^{21}$ The prohibition of dual nationality contributed to gender discrimination in nationality revocation measures. ${ }^{22}$ Women would lose their original nationality upon marriage with a foreign national-a policy justified by states' desire to prevent dual nationality and avoid mixed nationality marriages that could act as disruptors of social cohesion and blur nationalistic ideals. At the time, the majority of states also provided more generally for nationality revocation in response to the "voluntary act of acquiring another nationality'. ${ }^{23}$

Later, views on dual nationality as well as women's nationality rights changed and this picture changed with it. Many states no longer prohibit dual nationality, nor does international law seek its eradication, and women's equal and independent nationality rights are now nearly universally recognised. However, another form of unequal nationality deprivation has meanwhile grown in prominence. The duty to avoid statelessness became an international norm with an increasingly strong influence on nationality deprivation rules. ${ }^{24}$ In aid of this goal, states have come to limit the application of many denationalisation measures to citizens with more than one nationality, creating inequality in nationality deprivation measures between mono nationals and dual nationals. For instance, in a number of countries,

\footnotetext{
18 International Law Commission (1953), pp. 1-17.

19 States were listed per denationalisation ground they have in their national legislation. Some grounds specifically applied to naturalised citizens. Other times asterisks were placed behind countries listed under more general deprivation grounds to point out that these states have such a denationalisation ground in their legislation but only applicable to naturalised citizens.

${ }^{20}$ International Law Commission (1953).

21 Convention on certain questions relating to the conflict of nationality laws (1930), Preamble.

22 De Hart (2015), p. 171.

23 International Law Commission (1953).

24 Art. 1(1) of the 1954 Convention on the Status of Stateless Persons defines a stateless person as a person who is not considered as a national by any state under the operation of its law.
} 
denationalisation can take place upon long term residence abroad, not fulfilling military duties, or if a person is a threat to national security-unless it leads to statelessness. ${ }^{25}$ This means, in effect, that states can only apply denationalisation measures to dual or multiple citizens: they can be cast out of the political community in response to undesirable behaviour, whereas mono nationals involved in similar acts are not subject to this measure.

By making citizenship for naturalised and dual citizens conditional upon good behaviour, citizenship becomes a less secure status for specific groups of citizens and a less equal status. Citizenship stripping is an instrument that enables states to treat nationality policy as complementary to immigration laws, to continue to control inclusion and exclusion of citizens with a migrant background. As Macklin describes, deprivation of nationality allows states to affect a 'two-step exile: first, strip citizenship; second, deport the newly minted alien' ${ }^{26}$ Such deportation can affect people who have lived their entire lives or a large part of their lives in the country, have their family in the country, speak the language and do not know any other country as their home. When revoking someone's nationality, it not only shows the unequal status of citizenship, it also results in unequal exposure to the risk of deportation and exclusion. ${ }^{27}$

Unequal deprivation measures also affect society as a whole and undermine important democratic values. Citizenship is an enabler of social cohesion as it creates a feeling of belonging and equality. If it is made conditional for only specific groups of citizens, i.e. naturalised and dual citizens, this disrupts (efforts towards) social cohesion. Threatening specific groups with denationalisation measures creates a divide between those who are deemed 'real' citizens and 'others', underpinning a divide between 'native citizens' and those with a migratory background that can have a deep impact on the whole community. As we see in other fields, there is a growing intolerance for making distinctions between sub-groups of citizens. For instance, in the past decade, the Dutch government has formally ceased its use of the terms 'allochthones' and 'autochthones' in its internal and public communications because they were identified to be highly charged terms that have an exclusionary and degrading effect on groups of citizens. ${ }^{28}$ This confirms the need to also re-assess other distinctions with similar effect that are made between groups of citizens, including through denationalisation measures. The article will return to this matter later.

\footnotetext{
25 It should be noted that acquisition of another nationality can still result in loss of nationality in various circumstances. There are several regional analyses available of present-day provisions regarding deprivation of nationality, including, Global Citizenship Observatory (GLOBALCIT) (2017), Manby (2016), Van Waas (2014).

26 Macklin (2014).

27 Rubenstein and Lenagh-Maguire (2014).

28 Wetenschappelijke Raad voor het Regeringsbeleid (2016), p. 1.
} 


\section{Citizenship Stripping in the Counter-Terrorism Context: A Discriminatory Practice?}

Although, as the previous section has shown, "citizenship revocation has always been codified as States' last right to determine their composition, the use of the practice had reached near single digits following World War II' ${ }^{29}$ Once the legal bond of nationality has been forged, it has therefore generally come to be something to rely on-unless the citizen him or herself takes action to change citizenship and become a member of a different political community. ${ }^{30}$ But this picture has started to change as states have looked to nationality policy as a tool to tackle emerging national security threats.

The evolution of 'exceptionalist' counter-terrorism measures has now started to penetrate the realm of citizenship, challenging 'the prevailing view until the foreign fighter phenomenon came along [that] banishment or exile does not find a place as a matter of modern law and policy'. ${ }^{31}$ In the last decade, over a dozen countries have amended their legislation to give the state greater powers to unilaterally sever the legal bond with its own citizens on grounds that relate to national security or terrorism. These countries include Australia, Austria, Azerbaijan, Bahrain, Belgium, Bosnia and Herzegovina, Egypt, Kazakhstan, Kyrgyzstan, the Netherlands, the Seychelles, South Africa, Turkey and the United Kingdom. ${ }^{32}$

Although nationality deprivation has featured within the so-called 'legislative fever' ${ }^{33}$ with which many governments have responded to contemporary terrorism threats, its purpose is not clearly articulated. The political rhetoric invokes notions of deterrence, prevention-in particular through blocking return-and punishment. Yet no evidence has been produced for the effectiveness of this instrument and as set out below, the idea that citizenship stripping makes society more secure or helps to protect the democratic values that terrorists have 'turned their back on' is deeply questionable. $^{34}$

As was already the case for other rules on deprivation of nationality discussed in Sect. 2, many of these new or expanded powers do not apply equally to all citizens. In the United Kingdom, for instance, a dual national can be stripped of his or her British citizenship if this is deemed to be 'conducive to the public good' ${ }^{35}$ - a low bar that grants significant discretion to the Home Secretary, who wields the power to

\footnotetext{
${ }^{29}$ Emphasis added. Esbrook (2016), p. 1276. In this article, Esbrook offers an insightful overview of the history of and contemporary trends in citizenship deprivation across a number of countries. See also Weil (2012).

${ }^{30}$ The notable exception to this general trend is the persistence of large-scale denationalization and denial of nationality, affecting minority communities in a number of countries around the world, including in Myanmar, Kuwait and the Dominican Republic. See further, for instance, UNHCR (2017).

31 Burchardt and Gulati (2018), p. 13.

32 Research conducted in the context of the 2018 Expert Roundtable on Citizenship Stripping as a National Security Measure, on file with the authors.

33 Paulussen (2018).

34 Dearden (2018).

35 British Nationality Act 1981 (as amended on 28 July 2014), Sect. 40(1).
} 
invoke this measure. On the other hand, a mono citizen may be subject to the withdrawal of his or her British citizenship only if it was acquired by naturalisation and if two additional conditions are met: that 'it would be conducive to the public good to deprive them of their status because they have engaged in conduct "seriously prejudicial" to the UK's vital interests' and that 'the Home Secretary has reasonable grounds to believe that they could acquire another nationality'. ${ }^{36}$ The nationality of a mono citizen who is British by birth remains secure, regardless of his or her conduct. This legislation alone generates three 'classes' of British citizenship in terms of the security of status. Were three British citizens-one a mono citizen by birth, one a naturalised mono citizen and one a dual citizen-to conspire together to commit a terrorist act, the availability to the state of nationality deprivation as a recourse would differ among them, even if they were all equally culpable.

In this age of securitisation of nationality policy, it is dual nationals that are particularly affected. In Britain, there has been a significant upsurge in the deprivation of citizenship. In the 7 years from 2010 to 2016, a total of 47 people were stripped of their citizenship on the basis that to do so was 'conducive to the public good', then in 2017 this shot up to 104 people in a single year. ${ }^{37}$ All were dual nationals. In other countries where laws have been reformed in recent years, safeguards have been built into avoid statelessness-protecting the citizenship of mono citizens from interference, while revocation cases were initiated against dual nationals even as the ink was drying on the newly expanded deprivation powers. For instance, the media reported on the use of deprivation of citizenship against four 'convicted jihadists' by the Netherlands in 2017, a 'convicted terrorist' by Belgium in 2018 and five 'IS terrorists' by Australia in 2018. ${ }^{38}$ Again, all were dual nationals.

The upshot of this new trend in law and practice is the creation of 'a category of individuals who are placed under a special regime because they are considered to be undeserving of the same level of legal protection as other individuals' ${ }^{39}$ Targeting dual nationals, and in some cases specifically naturalised citizens, opens a pathway to indirect discrimination against minorities. In most countries, people from ethnic and religious minorities are over-represented in the population that holds naturalised citizenship or dual nationality. In the Netherlands, for instance, the majority of dual nationals are Dutch-Moroccans-who also, in fact, experience difficulties renouncing their Moroccan citizenship and so may be unable to become mono Dutch

\footnotetext{
36 British Nationality Act 1981 (as amended on 28 July 2014), Sect. 40(2). Note that the introduction of this rule in 2014 was met with significant criticism as the clause allows for the possibility of rendering a British citizen stateless. In practice, however, the last of the three requirements is unlikely to be fulfilled in a situation where a person is subject to deprivation of nationality due to conduct seriously prejudicial to the vital interests of a state. Such conduct will render the individual ineligible for naturalisation, due to common prescriptions relating to good conduct. As such, the utility of this provision is questionable.

37 Bureau of Investigative Journalism (2016); Secretary of State for the Home Department (2018), p. 27.

38 'Vier Jihadisten Nederlander-Af', 13 September 2017, https://www.bnr.nl/nieuws/politiek/10329596/ vier-jihadisten-nederlander-af; 'Rechter ontneemt veroordeelde terrorist nationaliteit', 14 June 2018, http://www.standaard.be/cnt/dmf20180614_03561686; 'Five terrorists involved with IS have been stripped of their Australian citizenship', 9 August 2018, https://www.sbs.com.au/news/five-terrorists -stripped-of-australian-citizenship.

39 Burchardt and Gulati (2018), p. 218.
} 
citizens. ${ }^{40}$ If nationality deprivation only applies to dual nationals, this is likely to lead to indirect discrimination against this group. ${ }^{41}$

The consequences of this are not benign, but part of a broader process that Choudhury describes as 'the production of suspect communities'. ${ }^{42}$ In the run up to the 2017 elections in the Netherlands, Prime Minister Mark Rutte (who succeeded in being re-elected), published an open letter in the country's newspapers which is telling of the normalisation of rhetoric that treats being part of the 'in-group' as contingent on the right kind of behaviour. ${ }^{43}$ In a letter that is addressed to 'all Dutch citizens' and which goes on to refer to equal treatment as a shared value that needs to be upheld, he writes:

We feel increasingly uncomfortable when people misuse our freedom to ruin things, when they came to our country precisely for that freedom. People who don't want to adapt, diss our habits or reject our values [...] I fully understand that people think: if you so fundamentally reject our country, I would rather you leave. I actually feel the same way. Act normally or get out. ${ }^{44}$

The instrumentalised use of citizenship stripping against dual nationals on the pretext of national security therefore should not be seen in a vacuum. Rather, it must be understood in a context in which some politicians 'deliberately stoke and exploit the national security anxieties of national populations [with the result that] they effectively stigmatize entire racial, ethnic, national and religious groups' ${ }^{45}$ This lends a real urgency to the scrutiny of such measures from the perspective of contemporary international law, which is what this article turns to next.

\section{International Law Standards: Mixed Messages?}

Starting with the 1930 Hague Convention on certain questions relating to the conflict of nationality laws, international law has progressively developed to constrain states' freedom to regulate acquisition and withdrawal of nationality. The affirmation of the right of every person to a nationality, in the Universal Declaration of Human Rights and later in many universal and regional treaties, has particularly influenced the shape of international norms. ${ }^{46}$ One specific rule that has emerged with a view to

\footnotetext{
${ }^{40}$ UN High Commissioner for Human Rights (2018), Jaghai and van Waas (2019).

41 UN High Commissioner for Human Rights (2018), paras. 42-43.

42 Choudhury (2017), p. 227.

43 See also on the 'Tolerated Citizen', Anderson (2013).

44 In the original language, this extract read: 'We voelen een groeiend ongemak wanneer mensen onze vrijheid misbruiken om hier de boel te verstieren, terwijl ze juist naar ons land zijn gekomen voor die vrijheid. Mensen die zich niet willen aanpassen, afgeven op onze gewoontes en onze waarden afwijzen. Aan alle Nederlanders [...] Ik begrijp heel goed dat mensen denken: als je ons land zo fundamenteel afwijst, heb ik liever dat je weggaat. Dat gevoel heb ik namelijk ook. Doe normaal of ga weg'. See https://www. vvd.nl/nieuws/lees-hier-de-brief-van-mark/.

45 UN Human Rights Council (2018), p. 17.

46 Spiro (2011).
} 
protecting the right to a nationality and is codified in both the 1961 Convention and the European Convention on Nationality (ECN) is the prohibition of withdrawal of nationality if it results in statelessness. ${ }^{47}$

This focus on avoiding denationalisation that renders a person stateless implicitly leaves it to states to determine whether and when to denationalise people, as long as they also hold another nationality. Indeed, states appear to have derived justification for targeting dual nationals for denationalisation from the international norms pertaining to statelessness. As the Netherlands explains in its explanatory memorandum on citizenship revocation measures:

Not withdrawing Dutch nationality if it would result into statelessness is one of the Kingdom's core obligations in countering statelessness. This results in a divide between Dutch citizens that hold one nationality and Dutch citizens with multiple nationalities, whereby the former cannot be denationalised. This is a legitimate divide. Preventing statelessness is the reason to revoke nationality in some cases and to not revoke nationality in other cases. ${ }^{48}$

Furthermore, the 1961 Convention admits a number of exceptions to its general prohibition of loss or deprivation of nationality that result in statelessness and these too appear to support the unequal application of the measure to different categories of citizen. More specifically, the 1961 Convention allows nationality to be revoked from naturalised citizens as a result of long-term residence abroad or if it was acquired by fraud-even if this leaves the person concerned stateless. Here, again, the possibility of citizenship being an unequal status seems to find support in international law: this norm tolerates policies that make naturalised citizens more susceptible to citizenship revocation policies than native-born citizens.

However, there are a number of other important international norms and general principles of law that are also relevant to the question of how unequal denationalisation regimes are to be understood. These include the prohibition of arbitrary deprivation of nationality ${ }^{49}$ and the principles of non-discrimination and proportionality that form integral elements of that prohibition. ${ }^{50}$ An assessment of current law

\footnotetext{
47 Arts. 7 and 8, 1961 Convention; Art. 7(3), European Convention on Nationality.

48 Explanatory memorandum on citizenship deprivation in the Netherlands, Kamerstuk 34,356-(R2064) no. 3, the original language of which reads: 'Het niet overgaan tot intrekking van het Nederlanderschap indien dit leidt tot staatloosheid is een van de kernverplichtingen waaraan het Koninkrijk zich gebonden heeft in het kader van bestrijding van staatloosheid. Dit leidt tot een onderscheid tussen Nederlanders met een enkelvoudige en Nederlanders met een meervoudige nationaliteit, waarbij in het eerste geval het Nederlanderschap niet kan worden ingetrokken. Anders dan de geconsulteerde organisaties suggereren is er hierbij evenwel sprake van een gerechtvaardigd onderscheid. De bescherming van staatloosheid is immers de grond om in het ene geval niet en in het andere geval wel tot intrekking van de nationaliteit wordt overgegaan.'

49 Art. 15 of the Universal Declaration of Human Rights; Art. 18(1)(a) of the Convention in the Rights of Persons with Disabilities; Art. 20(3) of the American Convention on Human Rights; Art. 4(c) of the European Convention on Nationality; Art. 29(1) of the Arab Charter on Human Rights; Art. 18 of the ASEAN Human Rights Declaration; Art. 24(2) of the Commonwealth of Independent States Convention on Human Rights and Fundamental Freedoms.

50 Brandvoll (2014).
} 
and practice on withdrawal of nationality leads to a rather different outcome if these standards are taken as the point of departure.

As set out in Sect. 3, where states target only naturalised citizens and/or dual citizens for denationalisation, this unequal treatment grounded on differences in citizenship status can bleed into indirect discrimination on the basis of ethnicity, race or religion - and therefore be considered 'arbitrary' under international law. As the UN Special Rapporteur on contemporary forms of racism, racial discrimination, xenophobia and related intolerance wrote:

Rarely do States explicitly discriminate on the basis of race, ethnicity or national origin in their citizenship stripping process. However, overbroad policies ostensibly rooted in national security concerns permit arbitrary enforcement-including arbitrary deprivation of citizenship-which in practice have a disproportionate effect on marginalised racial, national and religious groups. ${ }^{51}$

The statelessness-specific rules contained in the 1961 Convention must be interpreted in light of the broader principle of equality and non-discrimination that has been extensively codified in all core human rights treaties that were adopted after the 1961 Convention. ${ }^{52}$ According to the Human Rights Council (HRC), arbitrary deprivation of nationality, especially on discriminatory grounds such as 'race, colour, sex, language, religion, political or other opinion, national or social origin, property, birth, or other status, including disability' is a violation of human rights and fundamental freedoms. ${ }^{53}$

Law, policies and practices that disproportionately exclude or have a negative impact on a particular racial, ethnic or national group should also be considered as a breach of the prohibition of racial discrimination. This is true even in the absence of de jure or intentional discrimination. ${ }^{54}$

In fact, understood in this light, even the 1961 Convention itself can be read differently. Often overlooked in discussions of this topic, Article 9 of the 1961 Convention reads: 'A Contracting State may not deprive any person or group of persons of their nationality on racial, ethnic, religious or political grounds'. So, while the primary purpose of the 1961 Convention is to reduce the incidence of statelessness, the treaty itself recognises that there is a broader international principle at stake that must be applied as a blanket rule-separate from and regardless of the question of whether the result of denationalisation is statelessness. The ECN is also concerned

\footnotetext{
51 UN Human Rights Council (2018), pp. 17-18.

52 Among others in: the International Covenant on Civil and Political Rights, Art. 2; the International Covenant on Economic, Social and Cultural Rights, Art. 2; the Convention on the Elimination of Racial Discrimination, Art. 5; the Convention on the Rights of Persons with Disabilities, Art. 3; the Convention on the Rights of the Child, Art. 2; Convention on the Elimination of Discrimination against Women, Arts. 2 and 3. Please note that this is a non-exhaustive list of discriminatory grounds.

53 UN Human Rights Council (2016), para. 4.

${ }^{54}$ UN Human Rights Council (2018), p. 9.
} 
with 'avoiding discrimination in matters relating to nationality' ${ }^{55}$ and explicitly provides that 'Each State Party shall be guided by the principle of non-discrimination between its nationals, whether they are nationals by birth or have acquired its nationality subsequently'. ${ }^{56}$ From this it could be concluded that international law is giving off mixed messages about the legitimacy of rules under which the deprivation of nationality operates unequally.

Looking more closely, the UN Human Rights Committee explains that not every form of differential treatment constitutes discrimination. ${ }^{57}$ Severe national security risks and the fact that dual citizens are not prone to being rendered stateless in the way that mono citizens are could justify differential treatment, if such differential treatment has a legitimate aim and if it is proportionate. Barak clearly sets out the four components of the proportionality test:

(1) It is designed for a proper purpose (2) the measures undertaken to effectuate such a limitation are rationally connected to the fulfilment of that purpose (3) the measures undertaken are necessary in that there are no alternative measures that may similarly achieve that same purpose with a lesser degree of limitation and (4) there needs to be a proper relation (proportionality stricto sensu or 'balancing') between the importance of achieving the proper purpose and the social importance of preventing the limitation on the constitutional right. $^{58}$

A way to resolve the question of international law's apparent 'mixed messages' on this issue could then be to explore whether the unequal use of nationality deprivation as it is emerging today in the counter-terrorism context would pass this test.

The purpose of nationality deprivation as a counter-terrorism measure, as outlined in policy debates, is to strengthen national security by acting as a deterrent or preventative instrument and/or to punish those who turn their back on the state. While both the purposes of protecting security and effecting punishment are 'proper' aims and functions of the state, the further criteria of the proportionality test may pose a problem to the legitimacy of deprivation of nationality in pursuit of these aims-especially where it is of unequal application among citizens. For instance, will citizenship stripping actually effectuate either purpose if only a small sub-set of citizens is subject to the measure-i.e. what about the mono nationals and nativeborn citizens that pose a threat to national security? And, if deprivation of nationality is used as an added punishment for some citizens, but not others, how is this to be understood in light of the legal principle of ne bis in idem (to not be punished twice for the same crime) $?^{59}$

\footnotetext{
55 Preamble, European Convention on Nationality.

56 Art. 5(2), European Convention on Nationality.

57 UN Human Rights Committee (1989), p. 3.

58 Barak (2012), p. 3.

59 Note also that neither the 1961 Convention nor the ECN permits states to revoke citizenship of persons as a response to an ordinary crime. Both treaties refer to 'conduct seriously prejudicial to the vital interests of the State Party' as a ground for deprivation, calling further into question whether the purpose of punishment as such is legitimate for denationalisation.
} 
What evidence is there, in fact, that citizenship withdrawal has any impact on the threat of terrorist attacks? It imposes barriers to lawful return to the country, but terrorism is a global security threat that reaches beyond national borders. Terrorist attacks can be orchestrated from abroad and carried out by others in terrorist networks. Also, being denationalised does not keep a person out of a country: he or she may travel on false papers and continue to pose a threat to society. By taking away the bond of citizenship, governments may actually have less means at their disposal to track or take action against the person and so by turning citizens suspected of terrorism into foreigners, governments are exporting a security threat to the international community. It is therefore difficult to see how, in Barak's typology, this measure is 'rationally connected to the fulfilment' of the purpose increasing security. Indeed, as Esbrook summarised:

Expansion of citizenship-stripping proposals fractures international cooperation, provides tacit encouragement to States who use citizenship-stripping as a political tool to consolidate power, normatively sets the international community backwards in its evolution towards rights promotion and individual empowerment, and requires implementation of a new and extreme policy where existing law enforcement tools already exist. ${ }^{60}$

Finally, to assess the measure's proportionality, it is also necessary to ask whether less intrusive measures exist to counter terrorism and to protect national security and/or punish a citizen for his/her wrongdoings. Here, it is important to point out that mono nationals and native-born citizens are subject to a plethora of other measures set out in criminal law such as (preventive) detention, passport revocation, monitoring etc. ${ }^{61}$ In other words, states have found ways to address security threats posed by mono nationals without denationalising them. Why are these measures not simply applied in the same way to all nationals, without the state reaching for the added and far-reaching instrument of citizenship revocation for some? Doing so would prevent the discriminatory application of nationality deprivation measures and its concomitant effect on social cohesion. As Macklin puts it: 'A man who attacks his mother may be a terrible son who deserves to be prosecuted for his crime, but it is not the job of family law to disclaim him as the son of his mother. Citizenship law is not criminal law. Nor is it national security law. Nor should it be rigged to operate as a trap door that shunts citizens to immigration law'. ${ }^{62}$

On the contrary, taking seriously the protection of the right to a nationality and (re)asserting the equality of citizenship for all citizens is, in fact, a way for states to bolster the security and integrity of their society-one which accords with the ideals of liberal democracies. As Hirsch Ballin explains:

The methods of international terrorism are effectively directed against the foundations of societies based on trust in the rule of law [...] Once trust in

\footnotetext{
${ }^{60}$ Esbrook (2016), p. 1305.

61 Paulussen (2016), p. 13.

62 Macklin (2015b), p. 55.
} 
the law is battered, the door is open for political views that, while vehemently opposing such violent fundamentalists, mirror their culture essentialism: on their turn, populist politicians reject the idea of a free public space for all under the rule of law, and advocate an inward-looking nationalistic ideology. Thus, they undermine the idea of inclusive citizenship for all [and] paradoxically send out a message of confirmation to the terrorists that indeed a 'clash of civilisations' unfolds. ${ }^{63}$

It is this reading of the role and value of citizenship that underwrote Justin Trudeau's memorable speech at a Town Hall meeting during his election campaign in September 2015, where he stated unequivocally: 'A Canadian, is a Canadian, is a Canadian. You devalue the citizenship of every Canadian when you break down and make it conditional for anyone'. ${ }^{64}$ Following his election into office, Trudeau's government succeeded in repealing the expanded deprivation powers that had been introduced with the Strengthening Canadian Citizenship Act (SCCA) in 2015. While the trend at the time of writing is towards greater use of nationality deprivation as a security measure, the example of Canada shows that policy can be reversed and the democratic value of equal citizenship can be upheld.

\section{Conclusion}

Citizenship has been described by Bauböck as having 'an extremely sticky quality'. ${ }^{65}$ For most people, it indeed accompanies them unchanged and unchallenged throughout their lifetime and may therefore be experienced as a permanent and even immutable element of their identity. Yet, citizenship stripping is a measure that is as old as the existence of nationality law and seems to have always been an unequal measure-with some citizens holding a more precarious citizenship status than others.

The contemporary trend towards the securitisation of nationality policy has, perhaps belatedly, drawn attention to the discriminatory effect of this inequality. It has also helped to make visible the wider context of 'resurgent xenophobic and racist rhetoric and policies rooted in ethno-nationalism [that] not only harm noncitizens of any given nation [but] also make formal citizens who are ethnic, racial or religious minorities vulnerable to discrimination and intolerance'. ${ }^{66}$ Deprivation policies that target only naturalised or dual nationals have the effect of precluding the acceptance of these citizens as full citizens-undermining the function of naturalisation. The purpose of naturalisation processes is to affirm that a person has fully integrated into the community and is accepted as 'one of us'. Once admitted,

\footnotetext{
63 Hirsch Ballin (2018), p. 4.

64 Vice News, “A Canadian Is a Canadian”: Liberal Leader Says Terrorists Should Keep Their Citizenship', 28 September 2015, available at: https://news.vice.com/article/a-canadian-is-a-canadian-liber al-leader-says-terrorists-should-keep-their-citizenship (accessed 20 July 2018).

65 Bauböck (2015), p. 27.

66 UN Human Rights Council (2018), p. 14.
} 
naturalised citizens are equal to birth-right citizens and should be indistinguishable from them, able to participate in the democratic life of the state on the same terms. If their continuing-to-belong is contingent on behaviour, naturalisation serves little purpose and becomes indistinguishable from a form of conditional residence status. Where the naturalised citizen is mistrusted, citizenship stripping is put to work as a weapon which turns badly-behaved citizens into foreigners again, allowing them to be deported, or prevented from re-entering the country and thereby severing the link that has been so painstakingly built up and had received the highest form of legal recognition through the conferral of nationality. ${ }^{67}$

In respect of the distinction between mono and dual nationals, states have staked their case that this form of inequality is not just allowable under international law, it is mandated by international norms. It is true that it is in the interest of both states and individuals that statelessness be avoided and that this is affirmed by the human right to a nationality. But, as this article has discussed, just as nationality deprivation policies must be understood in their wider societal context, so must the duty on states to prevent statelessness be understood as part of a wider web of international standards and principles. The prohibition of arbitrary deprivation of nationality and the principles of non-discrimination and of proportionality must also be satisfied in any case in which a state seeks to strip one of its citizens of his/her citizenship.

How a truly rights-based approach to nationality might prevail where once a more technical approach was taken to the avoidance of nationality 'problems' can be illustrated by the evolution of women's nationality rights under international law (an area of law already referred to in Sect. 2). In 1930, the Convention on certain questions relating to the conflict of nationality laws provided that a woman could only lose her nationality on the basis of marriage with a foreigner if she acquires the nationality of her husband-a measure specifically aimed at preventing statelessness. ${ }^{68}$ By 1957 , the norm had evolved and the Convention on the Nationality of Married Women provided that "neither the celebration nor the dissolution of a marriage between one of its nationals and an alien, nor the change of nationality by the husband during marriage, shall automatically affect the nationality of the wife'. This marked an early stage in the recognition of women's independent nationality rights to men. Today, however, both approaches-while not unhelpful in addressing the nationality problems that women have historically faced-are superseded by the human rights standard contained in Article 9(1) of the Convention on the Elimination of All Forms of Discrimination against Women which states: 'States Parties shall grant women equal rights with men to acquire, change or retain their nationality'. By analogy then, while it remains of utmost importance to take measures to protect people from being rendered stateless, this norm cannot be invoked in a way that excuses from closer scrutiny policies that withdraw nationality from dual nationals only. As this article set out, it is unclear how nationality revocation as a counter-terrorism measure would ever pass the non-discrimination and proportionality tests prescribed by

\footnotetext{
67 Brandvoll (2014), p. 213.

68 League of Nations, Convention on Certain Questions Relating to the Conflict of Nationality Law, 13 April 1930, League of Nations, Treaty Series, Vol. 179, p. 89, no. 4137, Art. 7.
} 
international law and thereby satisfy the norm prohibiting arbitrary deprivation of nationality.

States have an arsenal of counter-terrorism measures that they can apply, equally, to all citizens. As such, a change of perspective on the legitimacy, merits and wisdom of invoking citizenship deprivation-an inherently unequal measure-to ensure national security appears to be overdue. These measures need to be challenged for their discriminatory nature and effects. ${ }^{69}$ Given the wider implications that unequal citizenship has in terms of creating a suspect group within society and eroding one of the key foundations of democratic society, states should in fact be lining up to abolish the outmoded measure of casting citizens out from their own political community.

Open Access This article is distributed under the terms of the Creative Commons Attribution 4.0 International License (http://creativecommons.org/licenses/by/4.0/), which permits unrestricted use, distribution, and reproduction in any medium, provided you give appropriate credit to the original author(s) and the source, provide a link to the Creative Commons license, and indicate if changes were made.

\section{References}

Anderson B (2013) Us and them: the dangerous politics of immigration control. Oxford University Press, Oxford

Barak A (2012) Proportionality, constitutional rights and their limitations. Cambridge University Press, New York

Bauböck R (2015) Whose bad guys are terrorists? In: Macklin A, Bauböck R (eds) The return of banishment: Do the new denationalisation policies weaken citizenship. EUI working papers RSCAS 2015/14. European University Institute, Florence

Belton K (2017) Statelessness in the Caribbean. Penn Press, Philadelphia

Blitz B, Lynch M (2009) Statelessness and the benefits of citizenship. Edward Elgar, Cheltenham

Brandvoll J (2014) Deprivation of nationality: limitations on rendering persons stateless under international law. In: Edwards A, van Waas L (eds) Nationality and statelessness under international law. Cambridge University Press, Cambridge, pp 194-216

Burchardt D, Gulati R (2018) International counter-terrorism regulation and citizenship-stripping lawsreinforcing legal exceptionalism. J Confl Secur Law 23:203-228

Bureau of Investigative Journalism (2016) Theresa May deprived 33 individuals of British citizenship in 2015. https://www.thebureauinvestigates.com/stories/2016-06-21/citizenship-stripping-new-figuresreveal-theresa-may-has-deprived-33-individuals-of-british-citizenship. Accessed 30 Oct 2018

Choudhury T (2017) The radicalization of citizenship deprivation. Critical Social Policy 37:225-244

Constantine G (2015) Nowhere people. http://www.nowherepeople.org/. Accessed 30 Oct 2018

De Hart B (2015) Regulating mixed marriages through acquisition and loss of citizenship. Ann AAPSS 662:170-187

Dearden L (2018) UK Government does not want captured Isis 'Beatles' returned to Britain for trial, says Gavin Williamson. Independent, 14 February 2018. https://www.independent.co.uk/news/uk/homenews/isis-beatles-uk-return-trial-gavin-williamson-defence-secretary-government-alexanda-kotey -el-shafee-a8209741.html. Accessed 15 Nov 2018

Edwards A (2014) The meaning of nationality in international law in an era of human rights: procedural and substantive aspects. In: Edwards A, van Waas L (eds) Nationality and statelessness under international law. Cambridge University Press, Cambridge, pp 11-43

Esbrook L (2016) Citizenship unmoored: expatriation as a counter-terrorism tool. Univ Pa J Int Law 37:1274-1329

${ }^{69}$ UN High Commissioner for Human Rights (2018) pp. 21-23. 
Global Citizenship Observatory (GLOBALCIT) (2017) Global database on modes of loss of citizenship. http://globalcit.eu/loss-of-citizenship/. Accessed 5 Nov 2018

Govil R, Edwards A (2014) Women, nationality and statelessness. The problem of unequal rights. In: Edwards A, van Waas L (eds) Nationality and statelessness under international law. Cambridge University Press, Cambridge, pp 169-193

Hirsch Ballin EMH (2018) Restoring trust in the rule of law. Asser research paper 2018-01. https://paper s.ssrn.com/sol3/papers.cfm?abstract_id=3109460. Accessed 30 Oct 2018

Institute on Statelessness and Inclusion (2017) The world's stateless: children. Wolf Legal Publishers, Oisterwijk

International Law Commission (1953) Nationality, including statelessness-national legislation concerning grounds for deprivation of nationality. http://legal.un.org/docs/?path=../ilc/documentation/engli sh/a_cn4_66.pdf\&lang=EFS. Accessed 12 Aug 2018

Jaghai S, van Waas L (2019) Stripped of citizenship, stripped of dignity? A critical exploration of nationality deprivation as a counter-terrorism measure. In: Paulussen P, Scheinin M (eds) Human dignity and human security in times of terrorism. T.M.C. Asser Press, The Hague

Macklin A (2014) Citizenship revocation and the privilege to have rights. Podcast. https://www.rsc. ox.ac.uk/news/citizenship-revocation-and-the-privilege-to-have-rights-professor-audrey-macklin. Accessed 2 Aug 2018

Macklin A (2015a) Kick-off contribution. In: Macklin A, Bauböck R (eds) The return of banishment: do the new denationalisation policies weaken citizenship. EUI working papers RSCAS 2015/14. European University Institute, Florence

Macklin A (2015b) On producing the alien within: A reply. In: Macklin A, Bauböck R (eds) The return of banishment: do the new denationalisation policies weaken citizenship. EUI working papers RSCAS 2015/14. European University Institute, Florence

Manby B (2016) Citizenship law in Africa. A comparative study. African minds, open society foundations. https://www.opensocietyfoundations.org/sites/default/files/citizenship-law-africa-third-editi on-20160129.pdf. Accessed 30 Oct 2018

Paulussen C (2016) Repressing the foreign fighters phenomenon and terrorism in Western Europe: Towards an effective response based on human rights. ICCT research paper. https://icct.nl/wp-conte nt/uploads/2016/11/ICCT-Paulussen-Rule-of-Law-Nov2016-1.pdf. Accessed 30 Oct 2018

Paulussen C (2018) Countering terrorism through the stripping of citizenship: ineffective and counterproductive. ICCT perspective. https://icct.nl/publication/countering-terrorism-through-the-stripping-ofcitizenship-ineffective-and-counterproductive/. Accessed 5 Nov 2018

Rubenstein A, Lenagh-Maguire N (2014) More or less secure? Nationality questions, deportation and dual nationality. In: Edwards A, van Waas L (eds) Nationality and statelessness under international law. Cambridge University Press, Cambridge, pp 264-291

Secretary of State for the Home Department (2018) HM Government transparency report 2018: disruptive and investigatory powers. https://assets.publishing.service.gov.uk/government/uploads/system/ uploads/attachment_data/file/727961/CCS207_CCS0418538240-1_Transparency_Report_2018_ Web_Accessible.pdf. Accessed 26 July 2018

Shachar A (2009) The birthright lottery. Citizenship and global inequality. Harvard University Press, Cambridge

Southan J (2018) World's top nationalities revealed: France is No. 1, U.S. ranks 27. Forbes, 26 April 2018. https://www.forbes.com/sites/jennysouthan/2018/04/26/worlds-top-nationalities-revealedfrance-is-number-one-us-ranks-27/\#7d1bb1d67d46. Accessed 20 July 2018

Spiro P (2011) A new international law of citizenship. Am J Int Law 105:694-746

UN High Commissioner for Human Rights (2018) Amicus Brief presented by the UN Special Rapporteur on contemporary forms of racism, racial discrimination, xenophobia and related intolerance before the Dutch immigration and naturalisation service. https://www.ohchr.org/Documents/Issues/Racis m/SR/Amicus/DutchImmigration.pdf. Accessed 5 Nov 2018

UN Human Rights Committee (1989) CCPR General Comment No 18 Non-Discrimination. http://www. refworld.org/docid/453883fa8.html. Accessed 15 Nov 2018

UN Human Rights Council (2009) Report of the Secretary-General on human rights and arbitrary deprivation of nationality. https://documents-dds-ny.un.org/doc/UNDOC/GEN/G09/175/12/PDF/G0917 512.pdf?OpenElement. Accessed 15 Nov 2018

UN Human Rights Council (2013) Report of the Secretary-General on human rights and arbitrary deprivation of nationality. http://www.refworld.org/docid/52f8d19a4.html. Accessed 15 Nov 2018 
UN Human Rights Council (2015) Report of the Secretary-General on impact of the arbitrary deprivation of nationality on the enjoyment of the rights of children concerned, and existing laws and practices on accessibility for children to acquire nationality, inter alia, of the country in which they are born, if they otherwise would be stateless. http://www.refworld.org/docid/56c42b514.html. Accessed 15 Nov 2018

UN Human Rights Council (2016) Human rights and arbitrary deprivation of nationality: resolution adopted by the Human Rights Council. http://www.refworld.org/docid/57e3dc204.html. Accessed 15 Nov 2018

UN Human Rights Council (2018) Report of the Special Rapporteur on contemporary forms of racism, racial discrimination, xenophobia and related intolerance. https://documents-dds-ny.un.org/doc/ UNDOC/GEN/G18/117/79/PDF/G1811779.pdf?OpenElement. Accessed 15 Nov 2018

UNHCR (2014) Special report: ending statelessness within 10 years. http://www.refworld.org/docid /572062254.html. Accessed 20 July 2018

UNHCR (2017) 'This is our home'. Stateless minorities and their search for citizenship. http://www. refworld.org/docid/59e4a6534.html. Accessed 20 July 2018

UNHCR (2018) Background note on gender equality, nationality laws and statelessness. 8 March 2018. http://www.refworld.org/docid/5aa10fd94.html. Accessed 30 Oct 2018

Van Waas L (2014) A comparative analysis of nationality laws in the MENA region. SSRN working paper. https://papers.ssrn.com/sol3/papers.cfm?abstract_id=2493718. Accessed 30 Oct 2018

Weil P (2012) The sovereign citizen. Denaturalization and the origins of the American Republic. Penn Press, Philadelphia

Weis P (1979) Nationality and statelessness in international law. Kluwer Academic Publishers Group, Dordrecht

Wetenschappelijke Raad voor het Regeringsbeleid (2016) Migratie en classificatie: naar een meervoudig migratie-idioom. WRR 2016. https:/www.wrr.nl/binaries/wrr/documenten/verke nningen/2016/11/01/migratie-en-classificatie-naar-een-meervoudig-migratie-idioom-34/Migra tie+en+classificatie+in+het+kort+V+34.pdf. Accessed 30 Oct 2018

\section{Affiliations}

\section{Laura van Waas ${ }^{1,2} \cdot$ Sangita Jaghai ${ }^{1,2}$}

Laura van Waas

Laura.vanWaas@institutesi.org

Sangita Jaghai

S.Jaghai@tilburguniversity.edu

1 Tilburg Law School, Tilburg, The Netherlands

2 Institute on Statelessness and Inclusion, Eindhoven, The Netherlands 